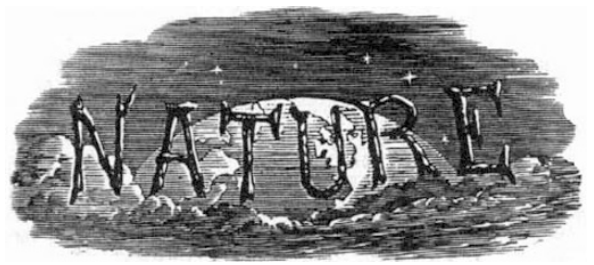

THURSDAY, FEBRUARY 23, I922.

Editorial and Publishing Offices:
MACMILLAN \& CO., LTD.,
ST. MARTIN'S STREET, LONDON, W.C.2.
Advertisements and business letters should be
addressed to the Publishers.
Editorial communications to the Editor.
Telegraphic Address: PHUSIS, LONDON.
Telephone Number: GERRARD 8830.

\section{The Function of English in Scientific Education.}

$T^{\text {H }}$

HE Report of Mr. Fisher's Committee on the

Teaching of English in England (pp. 394, H.M.S.O., I921, Is. $6 d$. net) has a refreshing novelty of outlook. As the serious study of English in the schools has an even shorter history than that of science, this Committee is little affected by pedagogic prejudices and vested interests, so that it is bold enough to treat all subjects taught in schools as coming within one or other of two groups, English and Science.

This classification calls for wide definitions; it is laid down that " in school, science must be, for teacher and for student, the methodical pursuit of truth and the conquest of the physical world by human intelligence and skill." The term " English" has in the past been interpreted in many ways. The public-school master of thirty or forty years ago would think of it as connoting geography, the history of England, and a little analysis and parsing, syntax and accidence. The Committee's definition is very different; it does not concern itself primarily with history or geography or with the study of language, but with the English language as a means of communication, oral and written, and with the content of books written in English as a storehouse of ideas, whether native or translated, and as an agent of emotional and æsthetic culture. Thus education is divided into "the training of the will (morals), the training of the intellect (science), and the training of the emotions (expression or creative art)," corresponding to the view that "the three main motives which actuate the human spirit are the love of goodness, the love of truth, and the love of beaut ."

$$
\text { NO. } 273 \text { O, VOL. IO9] }
$$

A separation of function of this kind has some value, if only to make us realise the necessity of each of the different components of a complete education. In practice, however, any one subject of study can and does perform several functions, overlapping those of other subjects which are akin to it. Thus some aspects of the study of English are of essential utilitarian value to a man of science, such as training in the power to write or speak clearly, lucidly, without ambiguity or prolixity, and if possible with a sense of style such that the reader may be attracted as well as instructed. But this power cannot be developed in the student without. traversing much of the same ground as would be covered.if the chief aim were the development of other faculties. So there will be economy of time and effort if English is used as the vehicle for an education in the humanities. It is universally agreed that, even for full efficiency in his own department, the science specialist must have such an education; it is the chief concern of the Committee to show how completely English can be made to fulfil that function.

The Committee mentions with approval the methods which have been developed at Osborne and Dartmouth in the training of naval cadets for their future career, which may be regarded as predominantly scientific, but in which they will need all the faculties of a liberally educated mind and character. For they may have to be diplomatists, tacticians, and strategists, and must certainly be leaders of men no less than practical scientilic workers; they must be equipped for controlling minds as well as machines. This problem is not peculiar to the Navy, though perhaps it is more obvious there owing to the close contact, under one controlling authority, between those who train and those who employ the product of the naval college, a contact closer than is practicable, for example, between schoolmasters and leaders in the business world. Hence the experience of Dartmouth may be of more than local interest.

It says much for the prescience of the Admiralty that it should have committed itself, so far back as $19 \circ 3$, on the advice of the eminent man of science, Sir Alfred Ewing, who was then Director of Naval Education, to the faith that, given adequate time and skilled treatment, most of the values hitherto judged to accrue solely from a classical education were to be derived from the study of English. The experience gained during the past eighteen years in acting on this belief has gone far to justify it, and it is satisfactory to note that the methods which have been elaborated are in close 
agreement, both in principle and detail, with those recommended by the present Committee.

There is little necessary connection between the study of the humanities and the teaching of languages; the latter properly falls under the head of a science, and the traditional connection arises from both having formerly been the province of one group of men. Before the days of the conflict of studies, the time devoted to Latin and Greek was far greater than was needed for the languages themselves, and the remainder was well spent on Literæ Humaniores. The present Report deals admirably with the question of the scientific and grammatical study of language; sections 254 to 266 are well worth reading in their entirety; but we are not concerned at the moment with the training of language specialists; we are, however, deeply interested in the problem of transferring to the teacher of English the functions formerly performed by the classics master in connection with the humanities. The first requisite for this transfer is to provide teachers adequately cultured; the next is to ensure the right use by them of the material available.

The Committee, therefore, had to decide what are the right methods of teaching; it also had to consider what modifications in these methods are appropriate to public elementary and preparatory schools, continuation, commercial, and technical schools, teachers' training colleges, and the universities; in addition, it felt constrained to prove that too little importance at present attaches to the study of English in all these institutions. Hence the Report covers so much ground that some search is needed to discover the teaching methods advocated.

A few extracts may, however, give some idea of the Committee's views. In commending recent progress it says :

"Exercises in both descriptive and imaginative writing, as well as practice in verse composition, in letter writing, and in dialogue, are common in the early stages. Many interesting experiments have been tried with a view to encouraging selfexpression. These include debates, improvised dialogues, and dramatic scenes, and ten-minute lectures by pupils, in class as well as in out-of-school hours." "There is a far wider range of reading than formerly. . . Rapid and enjoyable reading is no longer an exceptional thing; the class themselves take more part in the lesson and express their likes and dislikes freely.". . . Not less important than the art of writing is the art of speaking, which includes practice not only in framing questions and answers, but also in reading aloud, recitation, debating, and drama." "A reasonable study of phonetics by the teacher should enable him to give guidance and to correct some of the most common and jarring mistakes of pronunciation." "The rendering of literature by the voice is not a mere matter of mechanical correctness, but is the final result of sympathetic entry into the spirit of the writer, and without it no education in letters can be complete."

The interest in lessons on such lines need never flag; but a note of warning is sounded. Since the reading and writing of English have an intimate and personal touch for the Englishman, they form a perfect medium for a humane education, but there is a possibility that an enthusiast may press this advantage too far and thrust himself unbidden into an inner sanctuary of the adolescent soul. It is significant that the Committee has received warning of this danger from headmasters of public schools, and not from other teachers, for a man who works in boarding-schools is apt to know more of the real boy and his reticences than the master in sa day school. Hesitation on these grounds differs fundamentally from the objections of the conservative teacher whose sense of the ludicrous is stimulated by the thought of his class criticising a great author or acting scenes from a play, or of the disciplinarian who prefers the rigidity of dullness to the apparent disorder of a vividly interested class, or even of the man who feels that literature would be spoiled for the student by being read in school; but the Committee is probably right in holding that the danger is not great, and that in any event the gain is worth the danger.

In fine, to discover a medium of education in the humanities which is applicable to all sorts and conditions of Englishmen has been a vexed problem for many years, and the Committee has made an excellent case for leading us from the Abana and Pharpar of the classics to wash in the Jordan of English in order to secure a healthy and truly national system of education.

\section{Calcium Carbide and the Board of Trade}

\section{What's a WORD WORTH?}

"“ THE guestion is,' said Alice, 'whether you can make words mean so many different things.'

"'The question is,' said Humpty Dumpty, ' which is to be master-that's all." ",

$\mathrm{T}$ is written: "A rose by any other name would 1 smell as sweet"; perhaps, yet there are occasions when a name may be costly to play with. One of these occurred recently, an amount running into thousands of pounds having, it is said, changed hands in the effort to disestablish the meaning of a name. Called upon to interpret the Act, christened by our Legislature the Safeguarding of Industries Act but more appropriately described as an Act for 